\title{
The effect of foliar application of seaweed extract on potato
}

\author{
PAAVO KUISMA \\ Potato Research Institute, \\ SF-16900 Lammi, Finland
}

\begin{abstract}
The effect of foliar application of commercial seaweed extract on potato growth was studied in long-day conditions $\left(60^{\circ} 10^{\prime} \mathrm{N} 25^{\circ} 00^{\prime} \mathrm{E}\right)$ characterized by a cool and short growing season. The results showed that neither the doses, $0,5,10,201 /$ ha nor the spraying 24,45 , 58 days after the emergence had any remarkable influence on potato growth and yield if the other preconditions of production are in order. Only small, although insignificant benefit could be obtained with application done three weeks after emergence, clearly before tuber initiation.
\end{abstract}

Index words: seaweed extract

\section{Introduction}

Seaweed extract as a foliar fertilizer has been noted to have various beneficial effects on many crops (Button and Noves 1964, BLunDEN 1972). In particular, carbohydrate storage crops, such as a sugar beet, benefit remarkably from the use of seaweed extract (BLUNDEN et al. 1974). The use of seaweed extract as a foliar fertilization has also produced a significant increase in the yield of ware potatoes (BLunden and WiLdgoose 1977). In addition, seaweed extract is considered to improve the evenness of the size of the tubers, and to give a better cooking, eating and keeping quality. It is also thought to give protection from marginal frosts up to $-2^{\circ} \mathrm{C}$ (Chase Organics 1979).

From the point of view of plant nutrition, the usual application rates of seaweed extract are so low that the active compound, or compounds, must be effective in very low concen- trations. Brain et al. (1973) showed a high cytokinin activity, in a commercial seaweed extract, which is responsible for its many effects. In England, BLunden and WiLdGoOsE (1977) sprayed seaweed extract (SM3) on potato crop at the height of $45 \mathrm{~cm}$; this gave a yield increase similar to that with kinetin, which is a derivate of cytokinins.

Cytokinins are active at very low concentrations. They regulate a number of plant functions, including cell division (KODA and OKazawa 1983), protein and $\mathrm{CO}_{2}$ metabolism, enzyme formation, leaf ageing and senescence, shoot elongation and fruit set (TORREY 1976). The observations of BLUNDEN et al. (1974) that cytokinin treatment augmented the ratio of RNA to DNA suggest that a critical effect of cytokinins in senescence might be the maintenance of the protein synthesizing machinery, perhaps by regulating 
RNA (OSBORne 1962). Cytokinins also promote nutrient mobilization to the points at which they have been applied (Helgeson 1968).

On potatoes, cytokinins activate the tuber initiation and growth (PALMER and SMITH 1969, Forsline and Langille 1976). In sprouting seed tuber, the content of cytokinins increases in the surrounding of sprout bases (Engelbrecht and Bielińska-CZARNECKA 1972), and contributes to a break of dormancy (Hemberg 1970, Engelbrecht and Bielińska-CZarnecka 1972). Hartmans and van Es (1979) reported that kinetin, a derivate of cytokinins, increased the branching of sprouts on potato. The most beneficial effects on potato growth were reached at a kinetin concentration of $10^{-6}-10^{-7} \mathrm{M}$. The vigorous haulm growth which is caused by cytokinins, however, does not decrease the tuber yield (BADIZADEGAN et al. 1972).

Cytokinins are readily absorbed through leaf surface. Thus they are active only as a foliar application. If cytokinins are applied to the soil, their effects are lost (Brain et al. 1973).

Most experiments with seaweed extract have been done in short-day conditions. VIGNE and Lı (1974), however, recorded that under long-day conditions the applied cytokinins stimulate the stolons to form as air shoots, which causes decrease in yield. The aim of this research was to study the effects of the foliar application of commercial seaweed extract on potato growth and yield under growing conditions characterized by a long day and a cool and short growing season.

\section{Material and methods}

The experiment was conducted by the Department of Plant Husbandry, Helsinki University, on Viikki Experimental Farm $\left(60^{\circ} 10^{\prime} \mathrm{N} 25^{\circ} 00^{\prime} \mathrm{E}\right)$ in 1979 . The soil was a sandy loam and fertilized with a drilling fertilizer using a chlorine free NPK (8-11-12) at a rate of $1000 \mathrm{~kg} / \mathrm{ha}(80 \mathrm{~kg} \mathrm{~N} / \mathrm{ha})$. Each plot had two rows, $70 \mathrm{~cm}$ apart and $10 \mathrm{~m}$ long in a split-plot design with three replications. The chitted seed of the variety Record (30-45 $\mathrm{mm}$ ) was planted on May 24 with a semiautomatic planter at a distance of $30 \mathrm{~cm}$, representing 60 seedtubers a plot. Weed control was accomplished with metribuzin (Sencor $0,75 \mathrm{~kg} / \mathrm{ha}$ ) four days after emergence on June 20. Hilling was done on June 28. The trial was harvested on September 27, after the natural senescence of haulms.

The seaweed extract was applied at three different times according to the growth stages as main plots: the crop height of $25 \mathrm{~cm}$, the beginning of bloom, and two weeks after the beginning of bloom. The respective spraying dates were 24,45 and 58 days after emergence on July 10, July 31 and August 15. The doses of seaweed extract SM3 (Chase Org. (G.B.) Ltd.) 0 (water), 5, 10 and $201 /$ ha were in subplots. They were diluted $0: 100,1: 100,1: 50$ and $1: 25$ in water, respectively, and applied as a foliar spray with an experimental sprayer at a volume equivalent to $500 \mathrm{l} / \mathrm{ha}$.

According to the analyses of the Finnish State Institute of Agricultural Chemistry (Valtion Maatalouskemian laitos 1979), the constituents of SM3 were as set out hereunder:

\begin{tabular}{|c|c|c|}
\hline Nitrogen & (N) (Kjeldahl) & 0.14 \\
\hline Chlorine & (Cl) & 2.50 \\
\hline Calcium & (Ca) & 0.13 \\
\hline Magnesium & $(\mathrm{Mg})$ & 0.17 \\
\hline Iron & $(\mathrm{Fe})$ & 0.0037 \\
\hline Manganese & (Mn) & 0.0007 \\
\hline Iodine & (J) & 0.083 \\
\hline Selenium & (Se) & 0.01 \\
\hline
\end{tabular}

According to English analyses (JAMES 1967, Jones 1978), seaweed extract SM3 also contains $0.04-0.24 \% \mathrm{P}, 0.64-2.51 \% \mathrm{~K}$, $0.02-0.6 \%$ amino acids, $1-150 \mathrm{ppm}$ vitamins and, e.g., Molybdenum, Vanadium, Germanium, and other elements, but less than $2 \mathrm{ppm}$ in total. Undiluted seaweed extract SM3 has been estimated to have an activity equivalent to $125 \mathrm{mg}$ /litre kinetin in aqueous solution (BLUNDEN and WILDGOOSE 1977). 
Growth and yield analyses

In order to investigate the development of a stand, the height of three plants was measured once a week from June 25 to the end of August. The maturity of haulms was evaluated on a scale of $0-10(0=$ green, $10=$ dead $)$ on September 3. After the harvest the yields were screened into three groups using $35 \mathrm{~mm}$ and $55 \mathrm{~mm}$ riddles. Samples, of about $5 \mathrm{~kg}$, for laboratory analyses were taken at random. From the samples the specific gravity was determined using the under water weight. This was converted to a starch percentage according to the table of Halz and Bucholz. The laboratory samples were also used to determine the mean tuber weight by calculating the number of tubers in the sample. The DM content of tubers was determined from $200 \mathrm{~g}$ chopped tubers that was dried for $24 \mathrm{~h}$ at $100^{\circ} \mathrm{C}$.

The statistical difference in each treatment was evaluated by the split-plot analysis of var- iance. In order to get more information about the effects of different spraying doses, the variances of subplots were dispersed into variance components: water-seaweed extract means and seaweed extract on the average (Table 1 and 2). The significance levels for the results are shown in the usual manner. Comparisons of means were done according to Tukey's HSD (Steel and Torrie 1960).

\section{Results and discussion}

When seaweed extract was applied about six weeks after emergence, an increase in stem length was noticed by BLUNDEN and WILDGOOSE (1977). In this trial the height growth was very slightly affected by the spraying date or dose. In the beginning the potato vines grew a little faster on plots where $20 \mathrm{l}$ /ha seaweed extract had been applied three weeks after emergence, when the plants were about $25 \mathrm{~cm}$ high, and the height growth was still vigorous. The influence was strongest a week after ap-

Table 1. The analysis of variance of the potato height growth and the haulm senescence.

\begin{tabular}{|c|c|c|c|c|c|c|c|}
\hline \multirow[t]{3}{*}{ Factor } & \multicolumn{7}{|c|}{ Growth phase } \\
\hline & \multicolumn{3}{|c|}{$\begin{array}{c}\text { between } 1 \text { st }-2 \text { nd } \\
\text { spraying }\end{array}$} & \multirow{2}{*}{\multicolumn{2}{|c|}{$\begin{array}{l}\text { between } 2 \text { nd-3rd } \\
\text { spraying } \\
\text { August } 6 \text { August } 13\end{array}$}} & \multirow{2}{*}{$\begin{array}{l}\text { after } 3 \text { rd } \\
\text { spraying } \\
\text { August } 20\end{array}$} & \multirow{2}{*}{$\begin{array}{l}\text { Haulm } \\
\text { senes- } \\
\text { cence }\end{array}$} \\
\hline & July 16 & July 24 & July 30 & & & & \\
\hline Spraying dates $\mathbf{A}$ & - & - & - & ns & ns & ns & ns \\
\hline \multirow{4}{*}{$\begin{array}{l}\text { Spraying doses B } \\
\text { water }- \text { seaweeds } \\
\text { seaweeds } \\
\text { AB }\end{array}$} & ns & o & ns & ns & ns & ns & ns \\
\hline & ns & $*$ & ns & ns & ns & ns & ns \\
\hline & ns & ns & ns & ns & ns & ns & ns \\
\hline & - & - & - & ns & - & ns & ns \\
\hline
\end{tabular}

Table 2. The analysis of variance of the potato yield and quality.

\begin{tabular}{|c|c|c|c|c|c|c|c|c|}
\hline \multirow[t]{2}{*}{ Factor } & \multirow{2}{*}{$\begin{array}{l}\text { Tuber } \\
\text { yield } \\
\mathrm{t} / \mathrm{ha}\end{array}$} & \multicolumn{3}{|c|}{$\begin{array}{c}\text { Tuber size }(\mathrm{mm}) \\
\text { classes }(\%)\end{array}$} & \multirow{2}{*}{$\begin{array}{l}\text { Ware } \\
\text { yield } \\
\text { t/ha }\end{array}$} & \multirow{2}{*}{$\begin{array}{l}\text { Tuber } \\
\text { size } \\
\mathrm{g}\end{array}$} & \multirow[t]{2}{*}{$\underset{\%}{\mathrm{DM}}$} & \multirow[t]{2}{*}{$\underset{\%}{\text { Starch }}$} \\
\hline & & $<35$ & $35-55$ & $>55$ & & & & \\
\hline Spraying dates $\mathbf{A}$ & ns & ns & ns & ns & ns & ns & ns & ns \\
\hline \multirow{4}{*}{$\begin{array}{l}\text { Spraying doses A } \\
\text { water-seaweed } \\
\text { seaweeds } \\
\text { AB }\end{array}$} & ns & o & ns & ns & ns & $*$ & ns & ns \\
\hline & o & $*$ & ns & ns & o & $*$ & ns & ns \\
\hline & ns & ns & ns & ns & ns & ns & ns & ns \\
\hline & ns & ns & ns & ns & ns & ns & ns & ns \\
\hline $\mathrm{HSD}_{0.05}$ & - & $0.3 \%$ & - & - & - & $11.9 \mathrm{~g}$ & - & - \\
\hline
\end{tabular}




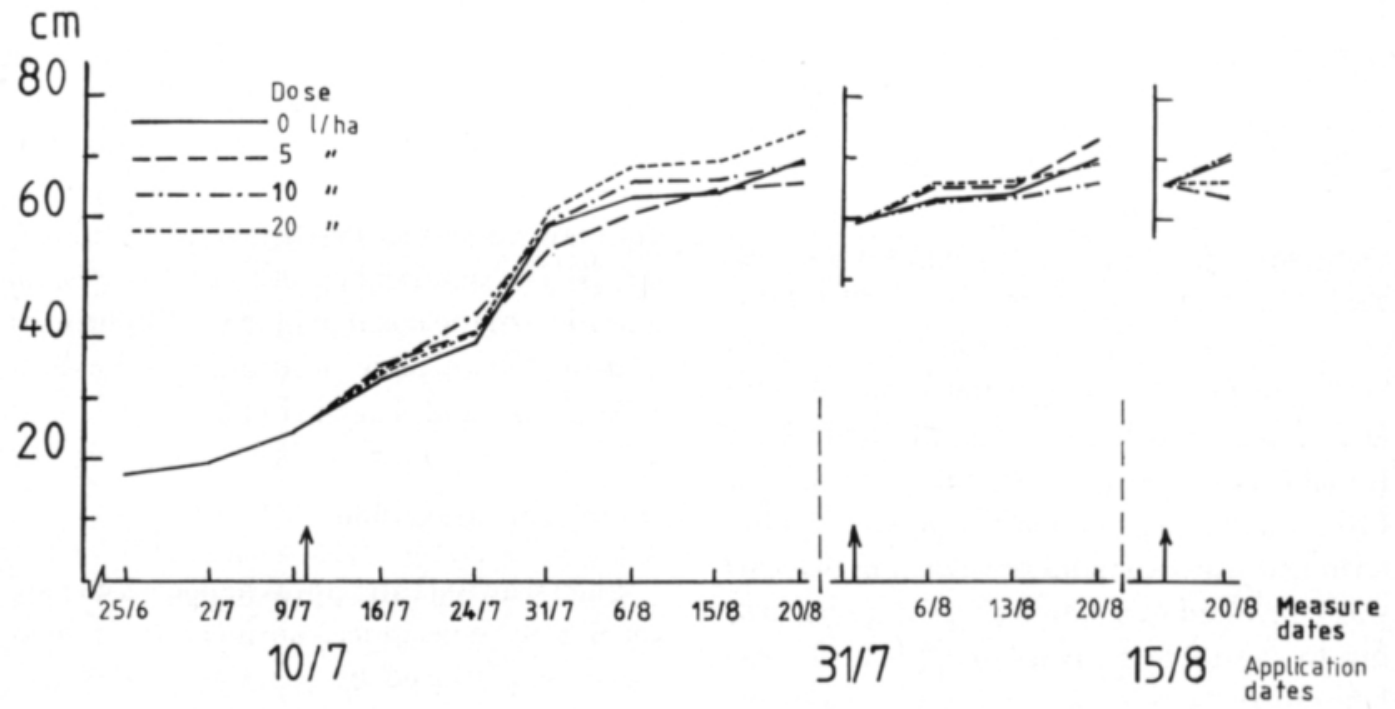

Fig. 1. The effects of seaweed extract on the height growth of potato haulms.

plication (Fig. 1). When the spraying was done at the same phase as BLUNDEN and WILDGOOSE (1977) used, about six weeks after emergence, in the beginning of bloom, or even two weeks later after the end of the height growth, there were no significant differences between application dates or doses.

According VIGNE and LI (1974), cytokinins - the most important compound of seaweed extract - easily stimulate the stolons of potato crop to form air shoots under a long day. This trial included no estimation of shoot or tuber number. However, the small, although insignificant, acceleration of senescence was seen in potato sprayed with seaweed extract (Table 3).

The foliar spray of SM3 seaweed extract did not produce any significant increase in the

Table 3. The effects of seaweed extract on the senescence of potato haulms $(0=$ green, $10=$ dried $)$.

\begin{tabular}{lcccc}
\hline Doses 1/ha & \multicolumn{3}{c}{ Application date } & \multirow{2}{*}{ Mean } \\
\cline { 2 - 3 } & July 10 & July 31 & August 15 & \\
\hline 5 & 5.7 & 4.3 & 5.3 & 5.1 \\
10 & 5.7 & 5.3 & 5.3 & 5.4 \\
20 & 5.7 & 5.3 & 5.3 & 5.4 \\
Mean & 5.7 & 5.0 & 5.3 & 5.3 \\
Untreated & & & & 5.1 \\
\hline
\end{tabular}

potato yields at any spraying dates or doses (Fig. 2). In this respect the results are similar to those of Dwelle and Hurley (1984), obtained in Aberdeen, Idaho, USA with cv. Russet Burbank; in this study foliar application of cytokinins, in seaweed extract or as kinetin, did not produce any measurable response. In the study of Dwelle and Hurley (1984), the best time for application, however, was later - the 2-week period directly following tuber initiation - than in this study where the

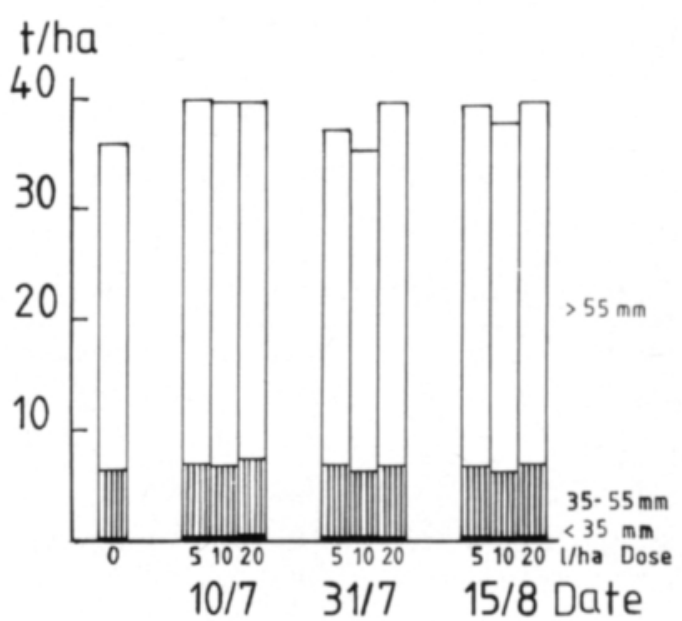

Fig. 2. The effects of seaweed extract on the tuber yield and its size distribution. 
Table 4. The effects of seaweed extract on the tuber size $(\mathrm{g})$.

\begin{tabular}{lrrrr}
\hline Doses 1/ha & \multicolumn{3}{c}{ Application date } & Mean \\
\cline { 2 - 3 } & July 10 & July 31 & August 15 & \\
\hline 5 & 96.9 & 93.8 & 92.0 & 94.2 \\
10 & 108.5 & 107.5 & 97.2 & 104.4 \\
20 & 99.7 & 96.2 & 105.1 & 100.3 \\
Mean & 101.7 & 99.2 & 98.1 & 99.6 \\
Untreated & & & & 107.2 \\
\hline
\end{tabular}

Table 5. The effects of seaweed extract on ware yield ( $\mathrm{t} / \mathrm{ha})$.

\begin{tabular}{lcccc}
\hline Doses 1/ha & \multicolumn{3}{c}{ Application date } & Mean \\
\cline { 2 - 4 } & July 10 & July 31 & August 15 & \\
\hline 5 & 39.60 & 36.60 & 39.00 & 38.40 \\
10 & 39.33 & 34.90 & 37.57 & 37.27 \\
20 & 39.21 & 39.30 & 39.36 & 39.29 \\
Mean & 39.38 & 36.93 & 38.64 & 38.32 \\
Untreated & & & & 35.63 \\
\hline
\end{tabular}

Table 6. The effects of seaweed extract on the DMcontent of tubers $(\%)$.

\begin{tabular}{lcccc}
\hline Doses 1/ha & \multicolumn{3}{c}{ Application date } & Mean \\
\cline { 2 - 3 } & July 10 & July 31 & August 15 \\
\hline 5 & 20.4 & 21.3 & 20.4 & 20.6 \\
10 & 20.7 & 21.1 & 21.6 & 21.1 \\
20 & 19.6 & 21.0 & 20.3 & 20.3 \\
Mean & 20.1 & 21.1 & 20.8 & 20.7 \\
Untreated & & & & 21.0 \\
\hline
\end{tabular}

only benefits, although slight, were reached with application done three weeks after emergence, clearly before tuber initiation.

In disagreement with the results given by BLUNDEN and WILDgoose (1977), the foliar applications of seaweed extract gave, on average, a higher proportion of tubers under 35 $\mathrm{mm}(\mathrm{P}<.05)$. This phenomenon was the strongest on the plots sprayed at height of plants about $25 \mathrm{~cm}$. Similarly, the average tuber size also was smaller (Table 4). The differences between the doses of seaweed extract can be considered to be minimal. Because of the very small proportion of tubers under $35 \mathrm{~mm}$, the ware yields (tubers over $35 \mathrm{~mm}$ ) nearly equally followed the gross yields (Table 5).

According to BLUNDEN and WILDgoose (1977), the type of response expected from a plant treated with a cytokinin suggests that carbohydrate storage crops would benefit from foliar application of seaweed extract. Trials on sugar beet showed that the plants treated with seaweed extract had a higher rootsugar content than the control plants (BLUN. DEN et al. 1974). In this study, the applied seaweed extract had no effect on the specific gravity or the dry matter content of tubers (Table 6). Dwelle and Hurley (1984) also reported that a foliar application of a commercial seaweed extract, CYTEX, in a sevenyear study had no significant effect on the specific gravity of potato in any trial year. Humpries (1958) reported that the synthetic cytokinin, kinetin, even depressed both the leaf area and dry matter production of plants of Majestetic potatoes.

The results of the experiment show that in long-day conditions, foliar fertilization with seaweed extract has hardly any economical importance if the other preconditions of production are in order. Although the seaweed extract was used in nearly the double amount of the recommended application of $11 \mathrm{l} / \mathrm{ha}$, the good status of nutrients in soil was able to cover the effects of the seaweed extract. In this respect, the results agree with the study of Dwelle and Hurley (1984). Some Finnish trials with a foliar fertilization (ANON 1979, 1983, 1984) also show that, in connection of a balanced base fertilization of NPK, seaweed extract given as a foliar application has very slight effects on the yields and starch contents of starch potato. 


\section{References}

ANon 1979. Lehtilannoskoe (A trial of foliar fertilization). Tärkkelysperunakoetuloksia 1979. p. 76-78.

- 1983. Lehtilannoituskoe (A trial of foliar fertilization). Tärkkelysperunakoetuloksia 1982. p. 71-74.

- 1984. Lehtilannoituskoe (A trial of foliar fertilization). Perunantutkimuslaitoksen koetuloksia 1983. Perunantutkimuslaitoksen julkaisu 1/1984. p. 61-63.

Badizadegan, M., Tafazoli, E. \& Kheradnam, M. 1972. Effect of $\mathrm{N}^{6}$ Benzyladenine on vegetative growth and tuber production in potato. Am. Potato J. 49: 109116.

Blunden, G. 1972. Proc. 7th Int. Seaweed Symp. p. 584. (Ref. Brain et al. 1973).

Blunden, G., Wildgoose, P.B. \& Nicholson, F.E. 1974. The effect of aqueous seaweed extract on sugar beet. Proc. 8th Int. Seaweed Symp. 3 p. (Manuscript.)

Blunden, G. \& Wildgoose, P.B. 1977. The effects of aqueous seaweed extract and kinetin on potato yields. J. Sci. Fd Agric. 28: 121-125.

Brain, K.R., Chalopin, M.C., Turner, T.D., Blunden, G. \& Wildgoose, P.B. 1973. Cytokinin activity of commercial aqueous seaweed extract. Plant Sci. Newsletter 1: 241-245.

Button, E.F. \& Noves, C.F. 1964. Effect of seaweed extract upon emergence and survival of seedlings of creeping red fescues. Agron. J. 56: 444.

Chase Organics 1979. From the sea CHASE S.M.3. for potatoes. Liquid extract of seaweed. Chase Organics (G-B) Ltd., Shepperton, England. Leaflet 3 p.

Dwelle, R.B. \& Huriey, P.J. 1984. The effects of foliar application of cytokinins on potato yields in southeastern Idaho. Am. Potato J. 64: 293-299.

Engelbrecht, 1. \& Bielinska-Czarnecka, M. 1972. Increase of cytokinin activity in potato tubers near end of dormancy. Biochem. Physiol. Pfl. 163: 499-504.

Forsl.ine, P.L. \& LANGil.te, A.R. 1976. An assessment of modifying of kinetin on in vitro tuberization of induced and non-induced tissues of Solanum tuberosum. Can. J. Bot. 54: 2513-2516.

\section{SELOSTUS}

\section{Merileväuutteen vaikutus lehtilannoitteena perunan satoon}

\section{Paavo Kuisma}

\section{Perunantutkimuslaitos, 16900 Lammi}

Merileväuutteen käytön lehtilannoitteena on havaittu tuottavan monia edullisia vaikutuksia useiden viljelykasvien kasvuun ja satoon. Erityisesti runsaasti hiilihydraat-
Hartmans, K.J. \& Es, A. van 1979. The influence of growth regulators $\mathrm{GA}_{3}, \mathrm{ABA}$, kinetin and IAA on sprout and root growth and plant development using excised potato buds. Potato Res. 22: 319-332.

Helgeson, J. 1968. The cytokinins. Science 161: 974981.

Hemberg, T. 1970. The action of some cytokinins on the rest period and content of acid growth-inhibiting substances in potato. Physiol. Plant. 23: 850-858.

Humpries, E.C. 1958. The effects of gibberellic acid and kinetin on the growth of Majestetic potato. Ann. Appl. Biol. 46: 346.

James, G.V. 1967. Sample analysis of seaweed extract. Western Counties Laboratories. Mimeogr. 2 p.

JoNES, R.T. 1978. The assay report of SM3. Portsmouth Polytechnic School of Pharmacy. Mimeogr. 2 p.

Koda, Y. \& Okazawa, Y. 1983. Characteristic changes in the levels of endogenous plant hormones in relation to the onset of potato tuberization. Japan. J. Crop. Sci. 52: 592-497.

Osborne, D.J. 1962. Plant Physiol. 37 (Ref. Blunden et al. 1974.)

Palmer, C.E. \& Smith, O.E. 1969. Cytokinins and tuber initiation in the potato, Solanum tuberosum L. Nature (London) 221: 279-280.

Steel, R.G.D. \& Torrie, J.H. 1960. Principles and procedures of statistics. 481 p. McCraw-Hill, New York.

Torrey, J.G. 1976. Root hormones and plant growth. Ann. Rev. Plant Physiol. 27: 435-459.

Valtion Maatalouskemian laitos 1979. Tutkimustodistus No. A 592/79. 1 p.

VIGNE, J.T. \& LI, P.H. 1974. The effect of simazine and cytokinins on potato tuber protein, nitrogen content and yield. Potato Res. 17: 327-332.

Ms received June 8,1988

teja varastoivien kasvien kuten sokerijuurikkaan on todettu hyötyvän merkittăvăsti merileväuutelannoituksesta. Erảănă selityksenä merilevăuutteen hyviin vaikutuk- 
siin kasvien sadonmuodostuksessa on esitetty sen korkeaa sytokiniinipitoisuutta. Perunassa sytokiniinit mm. voimistavat mukulanmuodostusta ja varsiston kasvua sekä parantavat ravinteiden hyväksikãyttöă.

Merilevăuutteen käyttōả perunan lehtilannoitteena tutkittiin Viikissă 1979. CHASE SM3 -merilevăuutteen kãyttömääraă vastasivat $0,5,10 \mathrm{ja} 20 \mathrm{I}: \mathrm{aa} /$ ha sekoitettuna 500 I:aan vettä/ha. Käsittelyajankohdat olivat 24,45 ja 58 päivaaă taimettumisesta. Koe osoitti, että hyvissă kasvuoloissa kăytettảessả kevaaăllă istutusvaiheessa tasapainoista lannoitusta (1 $000 \mathrm{~kg}$ Ylkv/ha) merileväuutteen hyöty lehtilannoitteena on hyvin văhäinen. Vaikka uutetta kăytettiin lähes kaksinkertainen annos (20 1/ha) suositellusta (11 l/ha), kasvualustan luontaisesti hyvä ravinnetila kykeni peittămaaãn merilevăuutteen mahdolliset lehtilannoitusvaikutukset. Ainoa văhäinen hyöty saavutettiin, kun kåsittely suoritettiin kolmen viikon kuluttua taimettumisesta, vielă selvăsti ennen mukulanmuodostuksen alkamista. 